\title{
Deciphering microbiota associated to Rhynchophorus ferrugineus in Italian samples: a preliminary study
}

\author{
M. Valzano, G. Achille, F. Burzacca, I. Ricci, C. Damiani, P. Scuppa, G. Favia \\ Scuola di Bioscienze e Biotecnologie, Università degli Studi di Camerino, Italy
}

\begin{abstract}
The Red Palm Weevil, Rhynchophorus ferrugineus (Olivier, 1790) is the most dangerous and deadly pest of date, coconut, oil, sago and other palms. Recently introduced in the Mediterranean basin, it became the most relevant insect pest for ornamental palms in the urban environment. Given the development of an innovative control method based on symbiotic control, we have performed a pilot project to decrypt the microbiota associated to both adults and larval stages of the insect to identify potential tools for biocontrol agents against the Palm Weevil. A number of bacterial species were found associated with the insect. In particular, species of the genera Lactococcus, Proteus, and others were detected.
\end{abstract}

\section{Introduction}

Rhynchophorus ferrugineus (Olivier, 1790) also known as the invasive Red Palm Weevil (RPW) (Wattanapongsiri, 1966) is one of the most destructive pests of date palms, the primary fruit tree of arid, tropical and sub-tropical areas including many Arab Gulf and North Africa countries (Esser \& Meredith, 1987; Bokhari \& Abuzuhari, 1992; Barranco et al., 1996).

Symptoms of infestation are the presence of tunnels in the trunk, oozing of thick sap from the tree, presence of fermented odor from the

Correspondence: Guido Favia, Scuola di Bioscienze e Biotecnologie, via Gentile III da Varano, University of Camerino (MC), Italy.

Tel. +39.0737.403.230 - Fax: +39.0737.403.290.

E-mail: guido.favia@unicam.it

Key words: Rhynchophorus ferrugineus, symbiont, microbiota, symbiotic control.

Received for publication: 18 September 2012.

Revision received: 8 November 2012.

Accepted for publication: 14 November 2012.

CCopyright M. Valzano et al., 2012

Licensee PAGEPress, Italy

Journal of Entomological and Acarological Research 2012; $44: e 16$

doi:10.4081/jear.2012.e16

This article is distributed under the terms of the Creative Commons Attribution Noncommercial License (by-nc 3.0) which permits any noncommercial use, distribution, and reproduction in any medium, provided the original author(s) and source are credited. fluid inside infested tunnels, breaking of the trunk and/or the toppling of the crown (Kaakeh, 2006).

An attack from $R$. ferrugineus might inflict death of the palm in 6-8 months (Murphy \& Briscoe, 1999) and infestation is often not visible until the tree has fallen down.

As a consequence of the heavy introduction of ornamental date palms in the Mediterranean Basin, $R$. ferrugineus has recently colonized different European regions (i.e., France, Greece, Spain, Albania, Cyprus and Italy) posing serious economical and environmental concerns (Llacer et al., 2010).

In Italy, the first report dates back to 2004 when the insect was detected on some plants of Phoenix canariensis in a nursery of the Pistoia province in Tuscany (Sacchetti et al., 2006). Later, $R$. ferrugineus infestations were detected in Sicily and Campania (since 2005), Latium and Apulia (since 2006), Abruzzo, Calabria, Liguria, Marche, Molise Sardinia (since 2007) and Basilicata (since 2010) (Longo \& Tamburini, 2005; EPPO, 2008; Massa et al., 2010).

For years, several control methods have been applied against $R$. ferrugineus and other weevil species within the Integrated Pest Management (IPM) strategy (Hallett et al., 1993; Rajamanickam et al., 1995; Abraham et al., 1999). This integrated approach mainly includes phyto-sanitation, which involves cutting down and burning of the infested palms, and the use of insecticides and pheromone traps for adult monitoring and mass trapping (Murphy \& Briscoe, 1999; Faleiro, 2006).

The use of a broad-spectrum of insecticides implicates a heavy environmental impact, especially for non-targeting invertebrate species. Therefore, the setting and applicability of alternative control strategies is of the greatest importance. In this context, the development of biocontrol methods has attracted much interest in the few last years. This mostly regards the employment of self-pathogens such as Pseudomonas aeruginosa, Beauveria bassiana (El-Sufty et al., 2007; Güerri-Agulló et al., 2010), different species of Bacillus (Banerjee \& Dangar, 1995; Salama et al., 2004; Longo \& Colazza, 2009) and yeasts (Dangar, 1997), while several studies have been conducted on the natural enemies of $R$. ferrugineus that might be successfully used as tools for its biological control (Murphy \& Briscoe, 1999; Hanounik et al., 2000; Salama et al., 2004).

Recently, much effort has been made to identify more effective and safer biological control agents against several insect pests (Sezen $e t$ al., 2005). In this framework, characterization of the microbiota associated with insect pest may provide additional tools for insect control.

In fact, there is much evidence to show that insect microbial flora could play an important role in the host biology, such as the production of indispensable compounds and essential nutrients (amino acids and vitamins), to provide protection towards natural enemies, and to influence some significant factors such as insect development, fertility, longevity, immunological competences and vector capability. The knowledge of microbiota composition associated to the target insect, especially those living in the gut, where they often accomplish fundamental functions for their hosts, is a necessary prerequisite for the development of symbiont-based approaches (Ricci et al., 2012; Kikuchi et al., 2012). 
In the last few years, a new strategy, called symbiotic control (SC) has been proposed to control insect pest (Douglas et al., 2007). The SC measure mainly refers to two main approaches: i) interference with microbial symbionts required by insect pests; and ii) the genetic manipulation of symbionts to deliver specific molecules against the insect and/or the pathogens they transmit.

There is still little information about RPW microbiota. Here we report the bacterial communities associated with larvae and adults of $R$. ferrugineus sampled in Central Italy and the identification of microorganisms that might be exploited for its biological control.

\section{Materials and methods}

\section{Samples collection and gut dissections}

Larvae and adults of RPW were captured on infected palms on the Cupra Marittima seafront (Ascoli Piceno, Marche Region, Italy; latitude $43^{\circ} 1$ '51'24 N; longitude 1351'31'68 E).

These were stored in plastic holders and carried to the Parasitology Laboratory of the University of Camerino. Insect surface was washed several times with $70 \%$ ethanol and alcohol was allowed to evaporate before further processing of the samples. Insects were fixed on a foam table and dissected with sterile needles and sterile fine-tip forceps. Intestinal tracts were placed in $50 \mu \mathrm{L}$ of Grind Buffer (1\% SDS, $25 \mathrm{mM}$ EDTA pH 8, $25 \mathrm{mM} \mathrm{NaCl}, 50 \mathrm{mM}$ Tris- $\mathrm{HCl} \mathrm{pH} \mathrm{8)} \mathrm{and} \mathrm{utilized}$ for DNA extractions.

\section{DNA extraction}

Samples were homogenized in $50 \mu \mathrm{L}$ of grind buffer using sterile polypropylene pestles and placed $30 \mathrm{~min}$ at $65^{\circ} \mathrm{C}$. After addition of $14 \mu \mathrm{L}$ of $8 \mathrm{M}$ Potassium Acetate ( $\mathrm{pH} 7.2$ ), the homogenates were kept on ice for $30 \mathrm{~min}$ and then centrifuged for $10 \mathrm{~min}$ at $13,000 \mathrm{rpm}$. DNA was precipitated in $100 \%$ ethanol. DNA pellets were dried and then rehydrated in $50 \mu \mathrm{L}$ of ultra-pure water for polymerase chain reaction (PCR) applications and the nucleic acid concentration estimated by spectrophotometer analysis.

\section{$R$. ferrugineus specific semi-nested polymerase chain reaction assay}

Three oligos were designed against 18S rRNA gene of our weevil species:

R18S-for (5'-ACGGGTAACGGGGAATCAGGGT-3');

Rhyncf-rev (5'-GTCGTAACCACGACGCGCAC-3') and

R18S-rev (5'-TAATCATTACCTCGGGGTTCCGA-3').

Each PCR mixture was prepared, under sterile conditions, in a final volume of $25 \mu \mathrm{L}$ containing: $1 \times$ PCR buffer, $0.25 \mathrm{mM}$ dNTPs, $10 \mu \mathrm{M}$ of each primers, $1 \mathrm{U}$ Dream Taq DNA Polymerase (Thermo Scientific Inc., Waltham, MA, USA) and $50 \mathrm{ng}$ of DNA. Reactions were run for $2 \mathrm{~min}$ at $95^{\circ} \mathrm{C}$ and cycled 30 times through $30 \mathrm{~s}$ at $95^{\circ} \mathrm{C}, 30 \mathrm{~s}$ at $60^{\circ} \mathrm{C}$ and $30 \mathrm{~s}$ at $72^{\circ} \mathrm{C}$. Finally, reactions were kept at $72^{\circ} \mathrm{C}$ for $8 \mathrm{~min}$. PCR products were visualized by electrophoresis on ethidium bromide agarose gel (1\%) in $0.5 \times$ TBE buffer under ultraviolet (UV) light.

\section{Bacterial DNA amplification by polymerase chain reaction}

Extracted DNAs were targeted for PCR reactions using the universal 16S rRNA bacterial primers 27F (5'-TCGACATCGTTTACGGCGTG-3') and 805R (5'-AGAGTTTGATCCTGGCTCAG-3'). Reaction mixtures were carried out in a final volume of $30 \mu \mathrm{L}$, using $1 \times$ PCR buffer, $0.25 \mathrm{mM}$ dNTPs, $10 \mu \mathrm{M}$ of each primers, $1 \mathrm{U}$ Dream Taq DNA Polymerase (Thermo Scientific Inc.) and 50 ng of DNA. Reactions were run for 2 min at $95^{\circ} \mathrm{C}$ and cycled 20 times through $30 \mathrm{~s}$ at $95^{\circ} \mathrm{C}, 30 \mathrm{~s}$ at $56^{\circ} \mathrm{C}$ and $30 \mathrm{~s}$ at $72^{\circ} \mathrm{C}$. Finally, reactions were kept at $72^{\circ} \mathrm{C}$ for $10 \mathrm{~min}$.

\section{Bacterial library constructions and colony screening}

To characterize the bacteria inhabiting $R$. ferrugineus intestinal tract, the 16S rRNA gene amplicons were purified using the DNA Extraction kit (Fermentas, Thermo Scientific Inc.) and were cloned by the pGEM $^{\circledR}-\mathrm{T}$ Vector System (Promega, Fitchburg, WI, USA). The recombinant plasmids were transformed into Escherichia coli JM109 competent cells (Promega, USA).

The transformed cells were plated onto LB agar supplemented with $100 \mathrm{~g} / \mathrm{mL}$ ampicillin, $0.5 \mathrm{mM}$ IPTG, $50 \mathrm{mg} / \mathrm{mL} \mathrm{X-Gal} \mathrm{and} \mathrm{cultured}$ overnight at $37^{\circ} \mathrm{C}$. White colonies were picked up and used in PCR reactions with the primer T7 (5'-AATACGACTCACTATAGGG-3') and Sp6 (5'ATTTAGGTGACACTATAGAAT-3'). The PCR reactions $(10 \mu \mathrm{L})$ contained $1 \times$ PCR buffer, $0.25 \mathrm{mM}$ dNTPs, $\mu$ M of each primer, 1 U Dream Taq DNA Polymerase (Thermo Scientific Inc). Reactions were run for $2 \mathrm{~min}$ at $95^{\circ} \mathrm{C}$ and cycled 20 times through $30 \mathrm{~s}$ at $95^{\circ} \mathrm{C}, 30 \mathrm{~s}$ at $52^{\circ} \mathrm{C}$ and $30 \mathrm{~s}$ at $72^{\circ} \mathrm{C}$. Finally, reactions were kept at $72^{\circ} \mathrm{C}$ for 8 min. PCR products were then resolved in an $1 \%$ agarose gel stained with ethidium bromide. To avoid the sequencing redundancy of the same clones, restriction analysis of the bacterial amplified inserts was performed. Each reaction was carried out in a final volume of $15 \mu \mathrm{L}$ containing: $1 \times$ of buffer, $10 \times Y\left(\right.$ Yellow)/Tango ${ }^{\mathrm{TM}}, 2 \mathrm{U}$ Hin6I, $2 \mathrm{U}$ of Hpa II, $2 \mathrm{U}$ of Bsu15I and $5 \mu \mathrm{L}$ of amplicon. The samples were incubated at $37^{\circ} \mathrm{C}$ for $1 \mathrm{~h}$ and $30 \mathrm{~min}$, and were subsequently loaded on ethidium bromide agarose gel $(2 \%)$ in $0.5 \times$ TBE buffer. All the clones exhibiting an exclusive restriction pattern were amplified in $25 \mu \mathrm{L}$ and purified through DNA Extraction Kit (Fermentas, Thermo Scientific Inc.) for sequencing.

\section{Sequencing}

Bacterial purified fragments were sequenced at the Eurofins MWG Operon Company (Ebersberg, Germany). Sequences were compared with the database at the National Centre for Biotechnology Information (NCBI) by using Basic Local Alignment Search Tool (BLAST) (http///blast.ncbi.nlm.nih.gov/Blast.cgi).

\section{Results}

\section{$R$. ferrugineus identification by specific semi-nested polymerase chain reaction assay}

A morphological analysis had initially been performed (EPPO, 2007) (Figure 1A-B). To confirm insect identity as RPW, a molecular screening was performed using two generic primers for Coleoptera/ Curculionidae and an internal primer specifically designed on the $18 \mathrm{~S}$ rRNA locus gene of $R$. ferrugineus.

A nested PCR assay was then applied to DNA of larvae, adult females and adult males (Figure 1C) with the aim to obtain a species-specific amplification product to precisely identify $R$. ferrugineus samples.

Indeed, two PCR products were detected: a $611 \mathrm{bp}$ fragment and a $428 \mathrm{bp}$ fragment. The smaller band represented the specific fragment for $R$. ferrugineus. To confirm their specificity, the DNA fragments of 428 bp were purified by gel excision and sequenced. Sequences showed $100 \%$ similarity with $R$. ferrugineus sequence in GeneBank (Accession n. EF125057.1) confirming the morphological identification of the samples used in the subsequent molecular studies.

\section{Analysis of bacterial libraries}

Three 16S rRNA bacterial gene libraries were established from total DNA isolated from midguts of adult female, adult male and larva previously characterized by both morphology and molecular analysis. 

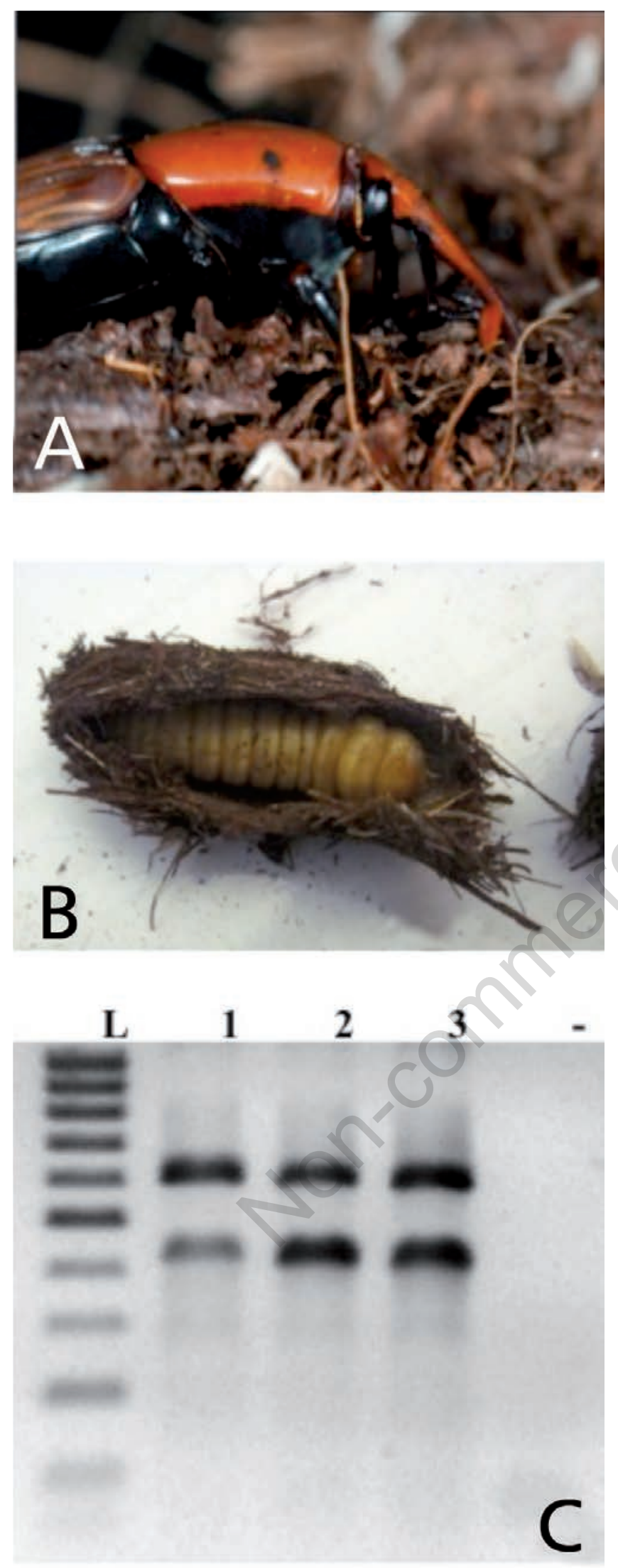

Figure 1. An adult (A) and a larva (B) of $R$. ferrugineus, sampled in Cupra Marittima. (C) Semi-nested polymerase chain reaction for the identification of $R$. ferrugineus. L, ladder $100 \mathrm{bp}$; 1, larva; 2, adult female; 3, adult male; -, no DNA control.
The majority of the clones in the library obtained by adult female were closely related to Lactococcus lactis (30\%) a Gram-positive lactic acid bacterium that is a common member of the microbial communities of termite gut and the major folate secretor together with Serratia grimesii into termites (Graber \& Breznak, 2005). Several clones instead gave high sequence similarity with Cedecea davisae (20\%) and with an uncultured Enterobacter sp. (20\%). Five clones were affiliated with an uncultured gamma-proteobacterium (25\%) while only one clone was related to an uncultured bacterium (5\%).

The analysis of the library obtained by adult male showed that the prevailing bacterium was once again L. lactis (66.7\%). Few further clones showed high sequence similarity with Proteus vulgaris (6.7\%). Interestingly, this Gram-negative bacterium has been reported to be associated to the digestive tract of Bombyx mori L. (Lepidoptera: Bombycidae) (Anand et al., 2010). Other clones are associated to Pseudomonas sp. (6.7\%) and uncultured bacteria (6.7\%).

Clones from the library obtained by larvae were identified as an uncultured Staphylococcus sp. (21\%), Pseudomonas sp. (15.8\%), Pseudomonas aeruginosa (10.5\%), an uncultured Acinetobacter sp. $(15.8 \%)$ and three uncultured bacteria $(21 \% ; 10.5 \% ; 5.2 \%)$ (Table 1$)$.

\section{Discussion and conclusions}

We have performed a pilot project aimed at characterizing the microbial communities associated with the midgut of both larvae and adults of $R$. ferrugineus specimens to identify possible candidates for the development of symbiotic control approaches of this insect pest. In this framework, some operational taxonomic units (OTU) have been identified offering interesting future perspectives in the elaboration of applied research-projects.

Different and specific bacterial species have been found in association with the insect at both developmental stages.

Some of the characterized species may perform important biological functions inside the RPW and could be exploited for future applications into the biological control of this pest. Two bacteria look particularly interesting: L. lactis, a cultivable Gram-positive lactic acid bacterium, which has been shown to be the prevalent bacterium in adults of both sexes, and $P$. vulgaris, a cultivable Gram-negative bacterium.

Lactic acid bacteria have been identified as common members of the gut microbiota of wood- and soil-feeding termites (Bauer et al., 2000; Eutick et al., 1978; Schultz \& Breznak, 1978; Tholen et al., 1997).

Besides the production of lactate and acetate (Schultz \& Breznak, 1979; Tholen et al., 1997), these bacteria have also been implicated in the recycling of excretory nitrogen in termite biosynthesis (Potrikus \& Breznak, 1980a, 1980b; Potrikus \& Breznak, 1981).

Strains of $L$. lactis and Serratia grimesii isolated from hindguts of the termite Zootermopsis angusticollis, were shown to exert a role in the secretion of 5 -formyl-tetrahydrofolate (THF). The THF acts as a $\mathrm{C}_{1}$ carrier in $\mathrm{CO}_{2}$-reductive acetogenesis, a microbial mediated process for energy production (Graber \& Breznak, 2005).

Furthermore, cross-feeding of 5 -formyl-THF by other community members is important for the growth of hindgut symbionts, such as Treponema primitia, an essential organism for termite nutrition and survival because of its ability to fix di-nitrogen and produce acetate.

Since $Z$. angusticollis and $R$. ferrugineus are both xylophagous insects, $L$. lactis strains in the weevil species likely execute very similar functions to those found in the termite.

Concerning $P$. vulgaris, it is known that guts of Lepidoptera contain bacteria that produce enzymes for carbohydrates digestion (Dillon \& Dillon, 2004). In particular, P. vulgaris, Citrobacter freundii, Serratia liquefaciens and Klebsiella sp., were reported to be cellulose-degrading bacteria and xylanolitytic bacteria (Prem Anand \& Sripathi, 2004). Bombix mori L. 
Table 1. Summary of the bacterial library screening.

\begin{tabular}{|c|c|c|c|c|c|}
\hline DNA sources & Bacterial species [Accession number] & $\begin{array}{l}\text { ce database } \\
\text { OTUs }(\%)\end{array}$ & $\begin{array}{l}\text { latch } \\
\text { Sequence similarity (\%) }\end{array}$ & $\begin{array}{l}\text { No. } \\
\text { clones }\end{array}$ & $\begin{array}{l}\text { Total } \\
\text { no. clones }\end{array}$ \\
\hline Midgut from adult $ㅇ$ & $\begin{array}{l}\text { Lactococcus lactis [CP002365]; [EU869288] } \\
\text { Cedecea davisae [HQ242718] } \\
\text { Uncultured gamma proteobacterium [JF833678] } \\
\text { Uncultured enterobacter sp. [JF703600] } \\
\text { Uncultured bacterium [GU562599] }\end{array}$ & $\begin{array}{l}30 \\
20 \\
25 \\
20 \\
5\end{array}$ & $\begin{array}{l}99-100 \\
99 \\
98-99 \\
97 \\
99\end{array}$ & $\begin{array}{l}6 \\
4 \\
5 \\
4 \\
1\end{array}$ & 20 \\
\hline Midgut from adult $\hat{\partial}$ & $\begin{array}{l}\text { Lactococcus lactis [CP002365]; [EU869288] } \\
\text { Proteus vulgaris [X07652] } \\
\text { Pseudomonas sp. [DQ118950] } \\
\text { Uncultured bacterium [HQ602799] } \\
\text { Uncultured bacterium [EU459323] } \\
\text { Uncultured bacterium [EU773759] }\end{array}$ & $\begin{array}{l}67 \\
6.6 \\
6.6 \\
6.6 \\
6.6 \\
6.6\end{array}$ & $\begin{array}{l}99 \\
99 \\
99 \\
99 \\
99 \\
99\end{array}$ & $\begin{array}{l}10 \\
1 \\
1 \\
1 \\
1 \\
1\end{array}$ & 15 \\
\hline Midgut from larva & $\begin{array}{l}\text { Staphylococcus sp. [EF061904] } \\
\text { Pseudomonas sp. [AF521651] } \\
\text { Pseudomonas aeruginosa [AE004091] } \\
\text { Uncultured bacterium [GQ476553] } \\
\text { Uncultured bacterium [AB286475] } \\
\text { Uncultured bacterium [JF276483] } \\
\text { Uncultured acinetobacter [FJ811887] }\end{array}$ & $\begin{array}{c}21 \\
15.8 \\
10.5 \\
21 \\
10.5 \\
5.3 \\
15.8\end{array}$ & $\begin{array}{l}95 \\
98 \\
97 \\
99 \\
99 \\
98 \\
99\end{array}$ & $\begin{array}{l}4 \\
3 \\
2 \\
4 \\
2 \\
1 \\
3\end{array}$ & 19 \\
\hline
\end{tabular}

OTUs, operational taxonomic units.

(Lepidoptera: Bombycidae) feeds on mulberry leaves that are mainly composed of pectin, xylan, cellulose and starch (Anand et al., 2010) and hosts $P$. vulgaris in its digestive tract. The xylophagous diet of RPW is comparable with that of Bombyx mori L. It is, therefore, reasonable to suggest that $R$. ferrugineus digestive tract could contain specific bacteria, such as $P$. vulgaris, able to produce enzymes that digest polysaccharides.

All of these characteristics, coupled with the fact that $L$. lactis and $P$. vulgaris are cultivable, make them potential candidates for the development of SC approaches, particularly those based on paratransgenesis and/or symbiont interference. However, further studies in this direction are required.

In larvae, we have found mostly bacteria of the genera Pseudomonas and Staphylococcus; interestingly, Pseudomonas is the only genus identified both in larvae and adults.

In conclusion, our pilot study, even though performed on a limited number of individuals, showed the potential of deciphering the composition of $R$. ferrugineus microbiota to identify symbionts and provide knowledge of insect-symbionts relationships in order to develop targeted biological control.

\section{References}

ABRAHAM V.A., NAIR S.S., NAIR C.P.R., 1999 - A comparative study on the efficacy of pheromone lures in trapping red palm weevil, Rhynchophorus ferrugineus in coconut gardens. - Indian Coconut J. 30: 1-2.

ANAND A.A., VENNISON S.J., SANKAR S.G., PRABHU D.I., VASAN P.T., RAGHURAMAN T., et al., 2010 - Isolation and characterization of bacteria from the gut of Bombyx mori that degrade cellulose, xylan, pectin and starch and their impact on digestion. - J. Insect. Sci. 10: 107.

BANERJEE A., DANGAR T.K., 1995 - Pseudomonas aeruginosa, a facultative pathogen of red palm weevil, Rhynchophorus ferrugineus. - J. Microbiol. Biotech. 6: 618-620.
BARRANCO P., DE LA PEÑA J.A., CABELLO T., 1996 - El picudo rojo de las palmeras, Rhynchophorus ferrugineus (Olivier), nueva plaga en Europa. (Coleoptera, Curculionidae). - Phytoma-España 76: 36-40.

BAUER S., THOLEN A., OVERMANN J., BRUNE A., 2000 Characterization of abundance and diversity of lactic acid bacteria in the hindgut of wood- and soil-feeding termites by molecular and culture-dependent techniques. - Arch. Microbiol. 173: 126-137.

BOKHARI U.G., ABUZUHARI R., 1992 - Diagnostic tests for red palm weevil, Rhynchophorus ferrugineus, infested date palm trees. - Arab Gulf J. Sci. Res. 10: 93-104.

DANGAR T.K., 1997 - Infection of red palm weevil, Rhynchophorus ferrugineus, by a yeast. - J. Plantation Crops. 2: 193-196.

DILLON R.J., DILLON V.M., 2004 - The gut bacteria of insects: nonpathogenic interactions. - Annu. Rev. Entomol. 49: 71-92.

DOUGLAS A.E., 2007 - Symbiotic microorganisms: untapped resources for insect pest control. - Trends Biotechnol. 25: 338-342.

EL-SUFTY R., AL-AWASH S.A., AL AMIRI A.M., SHAHDAD A.S., AL BATHRA A.H., MUSA S.A., 2007 - Biological control of red palm weevil, Rhynchophorus ferrugineus (col.: Curculionidae) by entomopathogenic fungus Beaveria bassiana in United Arab Emirates. - Acta Hort. 736: 399-404.

EPPO (European Mediterranean Plant Protection Organization), 2007 Rhynchophorus ferrugineus and Rhynchophorus palmarum. - EPPO Bull. 37: 571-579.

EPPO (European Mediterranean Plant Protection Organization), 2008 Data sheets on quarantine pests - Rhynchophorus ferrugineus. EPPO Bull. 38: 55-59.

ESSER R., MEREDITH J., 1987 - Red ring nematode. - Nematology Circular Florida Department of Agriculture and Consumer Services, Division of Plant Industry, n. 141, Gainesville, FL.

EUTICK M.L., O'BRIEN R.W., SLAYTOR M., 1978 - Bacteria from the guts of Australian termites. - Appl. Environ. Microbiol. 35: 823-828.

FALEIRO J.R., 2006 - A review of the issues and management of the red palm weevil Rhynchophorus ferrugineus (Coleoptera: Rhynchophoridae) in coconut and date palm during the last one hundred years. Int. J. Trop. Insect Sci. 26: 135-154. 
GRABER J.R., BREZNAK J.A., 2005 - Folate cross-feeding supports symbiotic homoacetogenic spirochetes. - Appl. Environ. Microbiol. 71: 1883-1889.

GÜERRI-AGULLÓ B., GÓMEZ-VIDAL S., ASENSIO L., BARRANCO P., LOPEZ-LLORCA L.V., 2010 - Infection of the red palm weevil (Rhynchophorus ferrugineus) by the entomopathogenic fungus Beauveria bassiana: a SEM study. - Microsc. Res. Tech. 73: 714-725.

HALLETT R.H., OEHLSCHLAGER A.C., GRIES G., ANGERELLI N.P.O., ALSHAREQI R.K., GASSUMA M.S., et al., 1993 - Field-testing of aggregation pheromones of two Asian palm weevils. - Pipoc Porim International Palm Oil Congress Update and Vision, Kualalumpur.

HANOUNIK S.B., HEGAZY G., ABBAS M.S.T., SALEM M., SALEH M.M.E. MANSOUR M.I., et al., 2000 - Biological control of Rhynchophorus ferrugineus as a major component of IPM. - Proc. 1st. Workshop on Control of date palm red weevil, Al-Ehsaa: 125-160.

KAAKEH W., 2006 - Toxicity of imidacloprid to developmental stages of Rynchophorus ferrugineus (Curculionidae: Coleoptera). - Lab. Field Tests Crop. Prot. 25: 432-439.

KIKUCHI Y., HAYATSU M., HOSOKAWA T., NAGAYAMA A., TAGO K., FUKATSU T., 2012 - Symbiont-mediated insecticide resistance. Proc. Natl. Acad. Sci. U. S. A. 109: 8618-8622.

LLÀCER E., DEMBILIO 0., JACAS J.A., 2010 - Evaluation of the efficacy of an insecticidal paint based on chlorpyrifos and pyriproxyfen in a microencapsulated formulation against Rhynchophorus ferrugineus. - J. Econ. Entomol. 103: 402-408.

LONGO S., TAMBURINO V., 2005 - [Gravi infestazioni di punteruolo rosso della palma.] - L'Informatore Agrario. 50: 73-74.

LONGO S., COLAZZA S., 2009 - [Il punteruolo rosso e il Castnide delle palme. - Regione Siciliana - Assessorato Agricoltura e Foreste. La ricerca scientifica sul Punteruolo rosso e gli altri fitofagi delle palme in Sicilia.] Centro Stampa Rubino, Marsala: 1: 7-11.

MASSA R., CAPRIO E., MIGLIORE M.D., PANARIELLO G., PINCHERO D., GRIFFO R., 2010 - [Punteruolo rosso delle palme: la soluzione delle microonde.] - Terra e Vita. 46: 10-13.

MURPHY S.T., BRISCOE B.R., 1999 - The red palm weevil as an alien invasive: biology and the prospects for biological control as a component of IPM. - Biocontrol News Inf. 20: 35-46.

POTRIKUS C.J., BREZNAK J.A., 1980a - Anaerobic degradation of uric acid by gut bacteria of termites. - Appl. Environ. Microbiol. 40: 125132. IN THE MAIN TEXT YOU CITED ONLY 1980

POTRIKUS C.J., BREZNAK J.A., 1980b - Uric acid-degrading bacteria in guts of termites [Reticulitermes flavipes (Kollar)]. - Appl. Environ.
Microbiol. 40: 117-124. IN THE MAIN TEXT YOU CITED ONLY 1980

POTRIKUS C.J., BREZNAK J.A., 1981 - Gut bacteria recycle uric acid nitrogen in termites: a strategy for nutrient conservation. - Proc. Natl. Acad. Sci. U. S. A. 78: 4601-4605.

PREM ANAND A.A., SRIPATHI K., 2004 - Digestion of cellulose and xylan by symbiotic bacteria in the intestine of the Indian flying fox (Pteropus giganteus). - Comp. Biochem. Physiol. A. Mol. Integr. Physiol. 139: 65-69.

RAJAMANICKAM K., KENNEDY J.S., CHRISTOPHER A., 1995 - Certain components of integrated management for red palm weevil, Rhynchophorus ferrugineus on coconut. -Mededlingen Faculteit Landbouwkundige-en-Toegepaste Biologische Watenschappen, Universiteit Gent. 60: 803-805.

RICCI I., DAMIANI C., CAPONE A., DEFREECE C., ROSSI P., FAVIA G., 2012 - Mosquito/microbiota interactions: from complex relationships to biotechnological perspectives. - Curr. Opin. Microbiol. 15: 278-284.

SACCHETTI P., CAMERA A., GRANCHIETTI A., ROSI M., MARZIALETTI P., 2006 - [Identificazione biologica e diffusione del curculionide delle palme, Rhynchophorus ferrugineus (Olivier).] - Informatore Fitopatologico. 20: 35-40.

SALAMA H.S., FOUDA M.S., EL-BENDARY M.A., ABDEL-RAZEK A., 2004 - Infection of red palm weevil, Rhynchophorus ferrugineus, by spore-forming bacilli indigenous to its natural habitat in Egypt. - J. Pest. Sci. 77: 27-31.

SCHULTZ J.E., BREZNAK J.A., 1978 - Heterotrophic bacteria present in hindguts of wood-eating termites [Reticulitermes flavipes (Kollar) ]. - Appl. Environ. Microbiol. 35: 930-936.

SCHULTZ J.E., BREZNAK J.A., 1979 - Cross-feeding of lactate between Streptococcus lactis and Bacteroides sp. isolated from termite hindguts. - Appl. Environ. Microbiol. 37: 1206-1210.

SEZEN K., DEMIR I., KATI H., DEMIRBAG Z., 2005 - Investigations on bacteria as a potential biological control agent of summer chafer, Amphimallon solstitiale L. (Coleoptera: Scarabaeidae). J. Microbiol. 43: 463-468.

THOLEN A., SCHINK B., BRUNE A., 1997 - The gut microflora of Reticulitermes flavipes, its relation to oxygen, and evidence for oxygen-dependent acetogenesis by the most abundant Enterococcus sp. - FEMS Microbiol. Ecol. 24: 137-149.

WATTANAPONGSIRI A., 1966 - A revision of the genera Rhynchophorus and Dynamis. - Department of Agricultural. Science Bulletin, Bangkok: 1: 1-328. 